\title{
How Unpopular Policies are Made: Examples from South Africa, Singapore and Bangladesh
}

\author{
Ingrid Palmary*, Thea de Gruchy**, ASM Ali Ashraf***, Chiu Yee Koh****, \\ Kellynn Wee****, Charmian Goh**** and Brenda S.A. Yeoh****
}

\begin{abstract}
In this article we contribute to the emerging knowledge on migration policy-making in two ways. Firstly, we address the relative lack of research on the gendered nature of migration policy-making. Secondly we contribute to understanding migration policymaking in postcolonial contexts. Based on case studies from Bangladesh, South Africa, and Singapore, we trace the drivers of policy change in these contexts and how the gendered vulnerability of the intended beneficiaries impacted the policy process. We found that there were four main drivers of migration policy-making in each of the countries. They were: the role-players in the policy change process, the debates that shaped the policy change, the research involved, and the political context in which the policy change took place. While our research drew on existing policy frameworks, it also showed that policy development is shaped by complex sociopolitical conditions.
\end{abstract}

\section{INTRODUCTION}

In recent years, migration policy-making has emerged as a field of specialist knowledge (Collinson, 1993; Guiraudon, 2000; Betts, 2011). Within this emerging literature, there are two omissions that this article contributes to addressing. Firstly, while some work has been done on gender dynamics in migration governance (for example, Oishi, 2005), the scope of this has been limited (Piper, 2006). Overall, in spite of gendered policy-making being a well-developed field outside of migration studies (see for example, Swers, 2013; Lombardo et al., 2009), scholarship on migration policy-making has been slow to attend to gender in the policy process. Secondly, much research on migration policy to date has been done in Europe and North America. This research has led to the development of useful theories and frameworks on how and why specific policies are made. Examples of these include Sabatier's Advocacy Coalition Framework (ACF) (2014) and research on how global norms affect national policy-making (Betts and Orchard, 2014; Risse et al., 1999; see also Birkland, 2014). However, there remains a lack of information and theorizing on how policy is made and implemented in postcolonial contexts (Piper, 2006), with some authors identifying a "theoretical lag" and empirical lacuna in Asia (Asis et al., 2009). Given that political and legislative arrangements vary dramatically in different country contexts, as do the social norms and public

\footnotetext{
* University of Johannesburg

** University of the Witwatersrand

$* * *$ University of Dhaka

$* * * *$ National University of Singapore
}

\section{(C) 2018 UNU-WIDER}

This is an open access article distributed under the terms of the Creative Commons Attribution IGO License https://creativecommons.org/lice nses/by/3.0/igo/legalcode which permits unrestricted use, distribution, and reproduction in any medium, provided that the original work is properly cited. In any reproduction of this article there should not be any suggestion that UNU or the article endorse any specific organization or products. The use of the UNU logo is not permitted. This notice should be preserved along with the article's URL. Vol. 57 (4) 2019 
expectations that drive policy change, evidence from more diverse contexts can benefit the development of these frameworks.

In this article we consider four factors that shaped the development of migration policy intended to protect the rights of vulnerable migrant women. Based on case studies from Bangladesh, South Africa, and Singapore, we trace the drivers of policy change in these contexts and how the gendered vulnerability of the intended beneficiaries impacted the policy process. Our research showed that policy development is shaped by complex socio-political conditions. Understanding these conditions can help to make policy change advocacy more effective and contextually relevant.

We employ the method of structured comparison to study three policy processes, conducted by the Refugee and Migratory Movements Research Unit (RMMRU) at the University of Dhaka in Bangladesh, the Asia Research Institute (ARI) at the National University of Singapore, and the African Centre for Migration and Society (ACMS), at the University of the Witwatersrand in South Africa. All three case studies employed the qualitative method of process tracing to map out the roles of key actors and institutions in influencing the policy under investigation (for more detail see Ashraf, 2016; Palmary and de Gruchy, 2016 and Koh et al., 2017a). Through a thematic and comparative analysis of all three studies, four common factors emerged as key to shaping the policymaking process in the three countries, albeit with varying impact and nature. We propose that by paying attention to these aspects of policy-making, researchers and advocacy organizations will be able to better understand, influence, and predict policy-making in similar postcolonial contexts.

\section{THE CASE STUDIES}

The findings from Bangladesh are based on a case study on the Domestic Workers Protection and Welfare Policy (DWPWP), which was approved by the Bangladesh government in 2015 (see Ashraf, 2016, for further details). While Bangladeshi activists have championed the rights and protection of domestic workers since the 1970s, concerted advocacy for domestic workers began in 2006 when they were excluded from the Labour Act of that year. Most domestic workers in Bangladesh are young women, often under the age of 18 , who migrate from rural to urban areas in search of employment. The vast majority of them take up work that involves their living in the home of their employer, which potentially exposes them to long working hours and high levels of abuse, and acts as a barrier to their being able to access help or mobilise. In many cases, domestic workers are relatives of their employers which makes the relationship between work and family obligation complex, as we will go on to describe.

The case study for Singapore investigated the mandatory weekly day off policy for foreign domestic workers introduced by Singapore's Ministry of Manpower (MOM) in 2014 (see Koh et al., 2017a for a fuller account). Singapore, a country with an ageing population, a high rate of formal employment for both men and women, and a growing proportion of dual-income families, is largely reliant on transnational, feminized migrant labour to fill the care deficit for the elderly and the young in the domestic sphere. Excluded from Singapore's main labour law, the Employment Act, state policies have also ensured that foreign domestic workers - women recruited mainly from less developed countries in the region such as Indonesia, the Philippines and Myanmar - are regulated as a transient workforce via a system of renewable two-year work permits that preclude permanent settlement, marriage to Singaporean citizens and permanent residents, pregnancy and giving birth in Singapore. This creates a context in which there are significant concerns about the human rights and welfare of migrant women working in the privatised domestic sphere, leading civil society groups to focus advocacy work on campaigning for better protection for these workers.

The South African case study is based on research into the Trafficking in Persons Act, which came into effect in 2015 (for the full report see Palmary and de Gruchy, 2016). South Africa 
signed the Protocol to Prevent, Suppress and Punish Trafficking in Persons, especially Women and Children (Palermo Protocol) in 2000, and ratified it in 2004, at which point concerns about the country as a place of "origin, destination and transit" for trafficking were gaining momentum. Throughout the early 2000s, organizations and individuals were mobilized by claims of vast numbers of women and children being trafficked for purposes of sexual exploitations. However, it was only in the build up to the 2010 FIFA World Cup held in South Africa that Parliament started to deliberate a Bill to specifically target trafficking, amidst concerns that women would be trafficked for sexual exploitation during this major sporting event (Bonthuys, 2012).

\section{THE CONTEXT IN WHICH POLICY IS MADE: WHAT POLICY AND FOR WHOM?}

The three case studies showed that the drivers of policy change were shaped by the type of policy being made and its intended recipients. Most significantly, in all three case studies, the policy had visible gendered contours and was intended to have an impact on a group of women deemed vulnerable. This gendered vulnerability of the policy focus had three main consequences that were common across the case studies.

Firstly, policies offering protection or additional services for migrants were often "unpopular" policies among the electorate and citizens. Congruent with other research done on this matter, citizens and policymakers often adopted "deservingness" frames to construe political attention and resources as being unfairly redistributed towards migrants (see, for e.g. Chauvin and GarcésMascareñas, 2014; Holms and Castañeda, 2016; Yoo, 2008). In this context, the protectionist nature of the policy cannot be divorced from the securitization of state borders. Indeed, as other authors have noted, protection and regulation often slide into one another (see Green, 1999 for illustrations). This ambivalent tension between the vulnerability of the intended beneficiaries of the policy and the presumed risks that they bring to the host society is one that has shaped the nature of the advocacy messages. In other words, migrant rights have not been a popular cause in any of the three countries, where, as we will show, notions of protection were frequently trumped by concerns about creating security risk or financial burdens for the state.

Secondly, across the case studies, the gendered nature of the policies was evident in the debates that took place. These included debates about whether women's domestic labour constituted work at all, as well as a moral emphasis in the discussions. In addition, the marginalized nature of the policy beneficiaries meant that their own voices were largely absent from the policy debates. These points are fleshed out in more detail below. It will suffice to say that gender and vulnerability were contextual factors that shaped the policy process.

\section{METHODS}

The method of structured and focused comparison offers a useful strategy for social and policy studies (Collier, 1993; George and Bennett, 2004). There are compelling reasons for choosing the three cases and for employing the method of structured comparison in this article. First, despite significant variations in the political systems of the country cases and the issues areas under investigation, the three cases offer useful insights into gendered migration policy-making in the global South, which has long remained an under-theorized area of study. Second, the cases were chosen purposefully to explore the types of policies being made, the key actors in policy-making, and the factors and processes through which policies were made. Third, the adoption of a comparative case study method allowed us to draw evidence from three diverse cases - domestic workers in Bangladesh, migrant workers in Singapore, and trafficking victims in South Africa - to learn about how 
international actors, intended beneficiaries, advocacy coalitions, and civil servants shaped the policy process, and whether any generalizable knowledge can be produced from a diverse group of case studies.

In all three studies, process tracing was the overall method used. Defined by Collier (2011) as "the systematic examination of diagnostic evidence selected and analysed in light of research questions and hypotheses" (p. 823), process tracing is a qualitative method through which claims can be made about the social and political phenomena that influence policy-making. In the case studies, documentary analysis and key informant interviews with identified stakeholders were used to inform stakeholder mapping and, ultimately, process tracing. Once initial stakeholders had been identified through documentary analysis, both purposive and snowball sampling were used to identify appropriate key informants involved in the policy process. The use of both documents and interviews acted as data triangulation. Stakeholder mapping then allowed researchers to isolate who the key actors were in the process and what institutional mechanisms they used to mobilize policymakers (Nagy Hesse-Biber and Leavy, 2011).

\section{FINDINGS}

In the liberal democracies of the industrialized west, policy change in immigration politics has mainly been explained by interest-based theories of the state including "a change in the balance of partisan power, the wielding of powerful economic influences, or attempts by the dominant faith to introduce or change a policy" (Stewart, 2012: 596). In this vein, Freeman's (2002) client politics model based on the US context gives a central role to the "organized public" such as civil society groups, businesses and employers, or think tanks as actors with the power to mobilize interests and shape the direction of policy. His approach assumes that "sectors that are dominant economically and politically will be more readily heard than subordinate sectors" (Freeman, 2002: 79). Criticisms of this approach have surfaced, as have alternative explanations of policy change relating to migration issues. For example, Consterdine (2015: 1436) drawing on work by Statham and Geddes (2006) found that, in Britain, "immigration policymaking was elite-driven and that Freeman strongly overstates the power of the organised public relative to national political elites". On the other hand, arguing that interest-based theories fail to fully explain immigrant policy trajectories, Stewart (2012) turns to the construction of narratives - particularly "apocalyptic" narratives requiring "heroic interventions" and predicated on the public's growing fear of crime and terrorism - to understand policy changes relating to legal driving privileges for unauthorized residents in Utah.

In this section, while we pay heed to the above explanations of immigration policy-making derived from the industrialized west, we draw primarily from our empirical evidence in proposing four drivers of policy change in the three case-study contexts. We argue that the focus of these policies on gendered vulnerability influenced these four drivers of policy change. The drivers we describe below are:

1) which role players were involved. Here, we consider the relative influence of different groups including international actors, local civil society, the impact of coalitions, and civil servants;

2) the debates that emerged;

3) the role of research and what kinds of knowledge and research influenced the policy; and

4) the political context in which the policy change occurred.

While recognizing the value of both interest-based and discourse-based theories in analysing policy change, we show that it is more crucial to understand how each of these drivers played a part in propelling change but in deeply contextualized ways. We also argue that those advocating for or 
developing new policy in a wider range of contexts beyond the sphere of western liberal democracies can pay attention to these policy influencers from a different vantage point.

\section{The role players involved in policy change}

In each of the case studies, the actors involved in making and shaping policy were a complex mix of international and local actors. In this section, we map out these stakeholders by loosely following the 3-Is approach, developed by Gauvin, which maps the various ideas, interests, and institutions that shape policy (for more detail see Gauvin, 2014).

\section{International actors}

One of the commonalities across all the case studies was the role of international actors in the policy-making process (see also Krut, 1997; Keck and Sikkink, 2014; for more). This influence was very particular in that, in all three cases, there had been some attention to the issue from local organizations and civil society groups for a very long time before the policy change. However, the introduction of international pressure increased the speed of policy development by the state and created heightened public debate on the topic through campaigns and lobbying. In this way it can be argued that international pressure played the role of catalysing change, or providing what the ACF calls an "external perturbation or shock" (Jenkins-Smith et al., 2014).

In the case of Singapore, the abuse of domestic workers and advocating for "Sundays off" had been on the agenda of NGOs since 2003. However, a Human Rights Watch report (Human Rights Watch, 2005) that brought the international spotlight on the exploitation of migrant domestic workers in Singapore, the demotion of Singapore to the Tier 2 Watch List in the United States' Trafficking in Persons (TiP) Report in 2010 (United States Department of State, 2010), and origin countries' increasing demand for better employment conditions for their overseas workers added fuel to the impetus for policy change. In the South African case, the catalyst was also a combination of being demoted to the Tier 2 Watch List in the TiP report (in 2005) and the build up to South Africa hosting the FIFA World Cup, which brought with it increasing anxiety around a presumed increase in trafficking during major sporting events (Bonthuys, 2012). In the Bangladesh case, the catalyst was the exclusion of domestic workers (as well as other informal workers) from the Labour Act (2006), which sparked frustration among rights groups and galvanized advocacy. For both South Africa and Singapore, the connection of the campaigns to international counter-trafficking interventions was significant for its ability to draw on pre-existing definitions of the problem and debates. For example, South Africa's concern that the World Cup would bring with it an influx of trafficking victims echoed concerns from previous major global sporting events, to the extent that the numbers of potential victims put forward by civil society ahead of the event was the exact number used prior to the FIFA World Cup in Germany in 2006 (Bonthuys, 2012).

Thus, it can be argued that, while international pressure does indeed play a role in policy change, it was not a singular determinant of it, nor was it responsible for putting the issue onto the policy-making agenda. Rather, international pressure played the role of catalyst in a context where there were already local NGOs and activists working on an issue. This does not necessarily suggest a close working relationship between local NGOs and international organizations, and, in fact, this relationship varied a great deal across countries. In South Africa some members of the anti-trafficking coalition did indeed work closely with international organizations or were part of them. In contrast, in Singapore there is considerable social and state scepticism towards the "foreign influence" of international organizations. This led to local civil society organizations selectively eschewing explicit alliances with international organizations in order to retain their credibility. 
Furthermore, countries' international reputations acted as a driver of policy change in a context where the focus on gendered vulnerability meant potential reputational damage for a country. For example, in Singapore, forces of international pressure came not only from global bodies such as the UN but also from wishing to avoid negative portrayals in international media outlets. In South Africa, key informant interviews suggest that the country's image as a beacon of human rights protection on the African continent meant that the demotion to the Tier 2 Watch List was a particular global embarrassment, thus galvanizing policy change. In all three countries, a concern with international reputation was mentioned as a reason for why policy was developed. It is frequently assumed in the literature that global advocacy pressure results in positive change for migrant workers at local and national levels. Indeed, in all three cases the motive of international organizations was to protect vulnerable groups. However, the assumption that issues framed as human rights issues, and supported by international civil society, are "good" and "progressive" meant that many of the claims made by civil society were not critically interrogated (see for example, Risse et al., 1999; and Betts and Orchard, 2014). For example, in the South African case it was argued strongly by some human rights organizations that trafficking legislation might be deflecting attention from more broad-based labour protections that were needed in the country, and that the legislation might result in increasing human rights abuses against sex workers.

International Conventions and treaties are often recognized as providing leverage for NGOs when advocating for human rights. However, ratification of a Convention can mean very little when it comes to its implementation (Betts and Orchard, 2014). The three case studies in this report exemplify this. For example, whilst South Africa did ratify the Palermo Protocol as early as 2004, it took a further 11 years for national counter trafficking policy to be implemented, even though national policy is a requirement of the Protocol. On the other hand, neither Bangladesh nor Singapore ratified the Convention concerning Decent Work for Domestic Workers (C189) when it was adopted in 2011 on the understanding that they could not commit to implementing its provisos but nevertheless did ultimately implement policies to protect migrant domestic workers. This indicates the tenuous relationship between Convention ratification and the actual implementation of the rights promoted and protected by the Convention. It further suggests that there are national norms that shape what signing Conventions means symbolically.

\section{Intended policy beneficiaries}

In all three case studies, the actual women for whom the policy was being developed were largely absent from the policy development processes and debates. The degree of and reasons behind this absence varied. For example, in Singapore, domestic workers were involved mainly as part of state-led focus groups in the build-up to the implementation of the day off policy. The absence of migrant domestic workers from advocacy debates is due to a confluence of reasons: foreigners are barred from promoting political causes in Singapore under the Public Order Act and may be deported or incarcerated should they go on strike or make other kinds of "political" gestures (Sim, 2015); migrant domestic workers enter Singapore on a visa under which conditions they can be sent home at will, rendering workers wary of explicitly participating in a political process which might result in deportation; and an additional host of other regulatory policies that render migrant women neither "seen" nor "heard" in the political arena (Yeoh and Annadhurai, 2008). In the South African case, no trafficking victims were involved in the policy development process in any way. Nevertheless, in all three cases, men and women who were significantly more powerful than the group that the policy was intended to benefit (on the basis of economic and other resources at their disposal and their citizenship status) largely advocated for and developed the policy. This had a notable impact on the nature of the messages that circulated in the advocacy and, to return to the 3-Is framework, the ideas that were dominating the debates; a point we return to in the next 
section. For example, it meant that the difficulties faced by employers became a dominant debate in the Singapore case - far more than the concerns of domestic workers. In the South African case, images of young women and children, with accompanying text indicating that the person in the picture could be someone you loved, were used to show the horror of trafficking. Most significantly, it shows that policy can be made with very little input from the groups it is intended to impact.

\section{Coalitions}

In all three cases, at the moment when the policy process began in earnest, NGOs and other interested parties formed coalitions. In Bangladesh, the Domestic Workers Rights Network (DWRN) emerged in 2006 and comprised 11 national trade unions and eight NGOs who focused on labour rights and domestic worker rights. In Singapore, the coalition was somewhat smaller, but consisted of three key NGOs which launched the day off campaign (Koh et al., 2017b). In South Africa, starting in 2004, various NGOs, some of which already had a long history in South African civil society, started to mobilize around trafficking. Whilst there was a definite affinity between NGOs, it was only in 2011 that the National Freedom Network (NFN) was founded and an active coalition of anti-trafficking campaigners formed.

Although being pro-trafficking or in favour of the abuse of domestic workers was not a position taken in any of the cases, there were nevertheless groups that objected to the specifics of the policy in question. In Bangladesh, the objection came from the Bangladesh Employers Federation (BEF), whose primary concern was that the policy was unrealistic given socio-economic conditions and the inability of employers to pay more for domestic help. A similar argument was put forward in Singapore, in which the private family unit (including live-in migrant domestic workers employed by family members), instead of public institutions, is expected to manage the work and the expense of round-the-clock care (Teo and Piper, 2009; Yeoh and Huang, 2009). In South Africa, dissenting arguments were that the nature and extent of trafficking was unknown and that much of the information informing policy development was incorrect. Thus, there were significant lobby groups contesting the form and content of the policy if not the principle.

There is one clear advantage to NGOs forming coalitions that was evident in these case studies: coalitions allowed NGOs to work on different phases of the policy change depending on their particular skills. Organizations with legal expertise were able to have an impact on the draft legislation, while service-oriented organizations with experience in providing direct services to migrant workers, and advocacy-oriented organizations well versed in fostering "transformative" civil society spaces, brought other strengths to the coalition (Yeoh and Annadhurai, 2008). For example, the DWRN in Bangladesh has extensive experience working with government and in policy development. In 2008, they met the Secretary of Labour and were tasked with developing a domestic workers' code of conduct, which the Labour Ministry then revised in keeping with existing laws. This was the foundation of the DWPWP. Even within this coalition, organizations such as the Bangladesh National Women Lawyers Association and the Bangladesh Legal Aid Services Trust were able to play a more central role in drafting the policy than other organisations due to their expertise and experience.

\section{Civil servants}

Civil servants themselves carry a number of complicated subjectivities into the process of policymaking: beyond their office, they occupy a number of different roles and positions. Additionally, they interpret and translate the rhetoric and meaning of governmental agendas policy-making in ways that are varying, relational, and complicated (Lipsky, 2010). In the South African case, one 
Member of Parliament who was involved in the Parliamentary Committee tasked with developing the Act was an active member of the anti-trafficking movement. In Singapore, the driving impetus behind the weekly day off policy was to create legislation that reflected what civil servants viewed as "broad social consensus" rather than the agenda of a "niche" group, resulting in a concessionary day-off policy tempered by a "buy-out" clause where workers are often pressured to trade away their days off for additional pay. In Bangladesh, there were civil servants who advocated for the passing of the DWPWP. However, key informants in the research also referred to an "invisible force" shaping policy-making, namely the bureaucrats who employed domestic workers and therefore had an investment in limiting their rights. In addition, MPs and bureaucrats were able to undermine some of the evidence that NGOs confronted them with by questioning the NGOs' motives. For example, there were concerns in the South African case study, in particular, that NGOs had alternative financial motives that might influence the data they presented to the state. MPs argued that NGOs' own funding rested on trafficking being a big problem and, therefore, their motivations may be self-interest rather than the rights of a vulnerable group.

While "interest groups" - international actors, NGO coalitions, civil servants and intended beneficiaries - all have a role to play in influencing policy, the balance of power among groups is highly contested and the rules of engagement much more complicated than allowed for by theories based on the policy-making experiences of western democracies. Pressure exerted by international actors, for example, can become double-edged in both catalysing and dampening policy change, depending on their relations to the state and civil society. While civil servants are key actors in translating policy into practice, they are often entangled in the countervailing demands of seeking social consensus, protecting the rights of vulnerable groups and pursuing self-interest.

\section{The debates that emerged}

In all three of the case studies, the central messages used for advocating for policy change were shaped by gender narratives.

As a consequence of the focus on gendered vulnerability, the resulting public debates about the policy were framed by concerns over the morality of the intended beneficiaries of the policy. This phenomenon, observed across all three countries, resonates with research around moral panics (Cohen, 2002; Critcher, 2008). Moral panics invariably turn conversations about groups of people who deviate from normative social practices (for example by selling sex) away from being about their protection or inclusion in society and towards identifying and eliminating their perceived deviance. In the South African case study, much of the debate on trafficking centred on women in sex work, in spite of there being many other potential trafficking victims. The moral focus of much of the debates was exacerbated by the fact that several of the awareness campaigns were led by religious organizations whose anti-sex work position was shaped by their moral and ethical stance against recognizing sex work as legitimate work. In the case of the day-off policy in Singapore, there were concerns that if female domestic workers were given a day off they might use that time to act in inappropriate and "immoral" ways such as "falling pregnant". In this way, the gendered nature of the policy meant that the debates set up migrant women's rights in conflict to social norms or morality, and the resultant policy was shaped by a broad discourse on appropriate gendered behaviour as much as by the needs and rights of female workers.

In addition, the gendered nature of the policy resulted in debates about the nature of women's work and whether it constituted "real" work. In Bangladesh, the fact that domestic work arrangements are frequently made between and within families means that they are popularly construed as a domestic rather than an employment arrangement. In Singapore, importing feminized domestic and care labour into the home further ossifies the gendered household division of labour, despite the increasing participation of Singaporean women in the formal labour force. In this gendered 
mode of labour substitution, domestic work is typically considered "women's work" and not "real work". For this reason, until more recent times, the Singapore government had rejected calls to prescribe minimum employment terms and conditions for domestic workers for fear that this would inevitably lead to "rigidities and inconvenience" for many families (Migrant Forum in Asia, 9 March 2006). Similarly, the discussions surrounding the Trafficking Act in South Africa were constantly framed by debates about the sale of sex and whether selling sex could ever be construed as "real" work. This took place in a context where there was significant activism aimed at decriminalizing sex work which argued that sex work was unlike any other form of paid labour. Therefore, each of these policies focused on policy-making where the appropriateness of state regulation was questioned on the basis of the view that such labour was deemed personal. For the two case studies on domestic work, there were extensive debates regarding whether and what kinds of domestic work actually constitute work and should thus be entitled to legal protections and, given the "unique nature of domestic work" (Koh et al., 2017a), what role the state should play in regulating domestic work. In the case study on trafficking in South Africa, the debates were often conflated with debates around the nature of sex work, whether it can be considered work, and whether it should be legal or illegal, formal or informal.

Importantly, in the case of Bangladeshi domestic workers, the focus was predominantly on internal domestic workers moving from rural to urban areas, while both of the other case studies focused on international migrants. It is significant to note that this did not affect the gendered vulnerability discourse so evident in the policy-making process. In other words, the debates on morality, labour and gender were similar, regardless of whether the policy beneficiaries were international or internal migrants. This is not to say that migration status did not matter at all and, in the case of Bangladesh, it is noteworthy that the DWPWP explicitly excluded international migrants. Yet civil society groups and lawmakers involved in the policy process argued that by adopting the Domestic Workers policy, the Bangladesh government could claim the moral high ground to press for decent work conditions for migrant domestic workers of Bangladeshi origin in the Persian Gulf. Other stakeholders saw the policy debate on internal migrant domestic workers as a first step toward a separate policy for international migrants. In a nutshell, although international migrants were excluded from the policy coverage, their concerns were well considered in the Bangladesh case.

Those who argued against the policy, or specific aspects of it, were typically concerned that implementation would not be feasible or would be too expensive. In South Africa, the Department of Home Affairs was particularly anxious that the trafficking definitions not be broad enough to allow a "back-door" for economic migrants to enter the country. In Bangladesh, there was an emphasis on the policy being impractical because of the additional expense that employers would incur. In the Singapore case, the concern was that employers would be unable to cope without domestic workers, given their reliance on them for round-the-clock care. Thus, as the population groups that the policies intended to protect were largely unskilled and transient, there were extensive debates that focused on the economic costs of their presence in a city or country as well as the social "burden" they constituted for the state and citizens. In all three countries, gendered discourses with strong moral undertones therefore have an important narrativizing role, and are "critical in conferring or withdrawing legitimacy, opening up or closing down options, or garnering or eliminating public support for a particular policy" (Stewart, 2012: 594).

In all cases, concessions were made by the coalitions. For example, in Bangladesh the policy was passed, but without reference to registration of domestic workers, minimum wages, or employers' responsibility for education and skills training. In addition, the policy excludes international domestic workers. In Singapore, the concession was that employers and domestic workers could mutually agree to pay extra in lieu of a day off if they so wished; however, since workers are saddled with high loans at the beginning of their contracts and lack bargaining power vis-à-vis employers and agents, this negotiation -meant to be neutrally conducted - is often in reality 
weighted against the workers' interests. In South Africa, there was a decision that the Department of Social Development would be responsible for determining whether someone was indeed a victim of trafficking (rather than relying on the victim's account) and, therefore, whether they were entitled to apply for asylum or obtain state support. Thus, although opposing positions were taken, concessions were a reality in the creation and implementation of the policies. In all cases, policy change could only take place by providing some degree of reconciliation between the proponents and opponents of the policy change.

\section{The role of research}

Research was used by advocacy coalitions and policymakers to effect change, albeit in ad-hoc and occasionally problematic ways. In each country, a number of studies had been conducted on the topic in question. In Singapore, for example, Human Rights Watch released research on the abuses faced by domestic workers in 2005. Similarly, in Bangladesh, local NGOs that were members of the DWRN conducted research that highlighted the abuses faced by domestic workers. In South Africa, there were key studies which focused on the extent and nature of trafficking, particularly one commissioned by the National Prosecuting Authority which was explicitly intended to guide the policy process (Human Sciences Research Council, 2010).

There are three noteworthy lessons about the way research was used for policy change. Firstly, the research was often questioned and contested. For example, in Singapore, the then-Minister of Manpower who was interviewed on the BBC argued that the Human Rights Watch report misrepresented and exaggerated the extent of "maid abuse" in Singapore, and that the standards of research were flawed (Mulchand, 2005). These debates about the credibility of research were perhaps the most intense in South Africa. There was no doubt that some of the research (including that commissioned by the National Prosecuting Authority) was extremely flawed and there was some doubt about whether any research had in fact been done or whether popular mythologies had simply been written in the form of research. On two occasions, Africa Check (an organization that checks the accuracy of claims made, particularly in the media) has dismissed the numbers of trafficking victims cited as unestablished. (See https://africacheck.org/reports/are-30000-kids-trafficked-into-south-africas-sextrade-every-year-the-claim-exaggerates-the-problem). In response, organizations producing some of this research argued that those challenging it were denying trafficking. Similarly, in response to civil society research reports and statements about the injustices faced by migrant workers, Singapore's Ministry of Manpower often quotes a government survey which finds that "nine out of ten foreign workers are satisfied in Singapore" (Ministry of Manpower, 2014), hence pitting one formulation of knowledge against another and declaring a particular source more authoritative. In this way, what constituted credible research was frequently subjected to debate. Often, the form this contestation took was to question the motives of those producing the research, suggesting they were biased.

Apart from questioning the credibility of NGO-produced research, policymakers were remarkably passive in their consumption of research. Respondents in the South African case study noted that they did not seek out research when developing policies, due to budget constraints. Rather, they relied on researchers coming to them with findings. In spite of this, respondents did value research and were eager to have more sound evidence on which to base policy-making. This suggests that there is a clear role for researchers if research can be used to influence the nature of the debates. Our findings thus suggest that in these contexts research was not a primary driver of policy change but once a policy course had been established there was scope for research to have an impact.

\section{The political context}

In all three case studies, the political context was an important shaper of the policy process. What is noteworthy from all of the studies is that the policies took almost a decade to develop. In most 
instances the topic for policy development was initiated, but then was not developed further until a catalyst, for example international pressure as discussed above, emerged. Government officials in Bangladesh attributed this to the fact that there are many policy priorities at any one time. However, several NGOs suggested that there were more sinister reasons for the delays. These included civilian bureaucrats' own investments in not passing some policies, such as those protecting domestic workers, as well as their concerns about whether policy could be implemented and what nonimplementation would mean.

Three factors can explain how the political system in Bangladesh conditioned domestic workers policy development. First, since the fall of a military dictator and restoration of parliamentary democracy in 1990, Bangladesh has seen a thriving civil society with vocal position on social development issues, especially on gender and workers' rights. As a result, when the members of pro-worker advocacy coalition DWRN first raised a demand for adopting a new policy on domestic workers in 2006 and later presented a formal letter to the Secretary of Labour Ministry in 2008, they had acquired considerable experience in both grassroots activism and policy advocacy. This experience proved to be an advantage in negotiating a policy framework for the domestic workers in the country. Second, the longstanding presence of a mid-ranking civilian bureaucrat in the Labour Ministry gave stability to the policy dialogue between government and the DWRN. The concerned bureaucrat attended all the meetings between 2008 and 2015 and had developed a rapport with the trade union leaders and NGO activists who contributed to drafting the policy. Third, the policy was adopted by the Awami League government, which has enjoyed support from the left-wing political parties. It was in this context that a veteran labour activist-cum-lawmaker, who also held the chair of parliamentary standing committee on Labour Ministry, managed to play an active role in supporting the policy process.

In South Africa, during the 1980s and 1990s the South African NGO sector expanded as its role in advocating for democratic change grew. International funding supporting the anti-apartheid movement ensured that through the 1990s this sector was strong in terms of resources and skills. Thus, throughout the 1980s the relationship between the NGOs and the South African state was highly antagonistic and conflictual. After the first democratic elections in 1994, the relationship changed dramatically to one of mutual support. Ironically, this has weakened the NGO sector in some ways, in that many people and organizations that had an overtly anti-apartheid stance were absorbed into government after the democratic elections. In addition, funding that supported the work of NGOs was, after democracy, often changed into bilateral funding and channelled through the South African government (see Habib and Taylor, 1999). After 2000, there was a re-emergence of more hostile relationships between NGOs and the state. This growing suspicion and hostility could be seen for example in the ways that policymakers in South Africa at times represented NGOs as changing research findings on the basis of selfinterest.

Thus, what clearly had an impact on how the policy was shaped was the relationship between NGOs and policymakers. In all three case studies, respondents pointed to policymakers' suspicions that NGOs' motives were self-serving. Perhaps connected to this, NGOs tended to have more success in accessing MPs if they had access to a particular, and particularly responsive, MP or if they had a long history of working with government.

In Bangladesh, in spite of general suspicion about NGOs being the norm, an NGO coalition was assigned the task of drafting the initial policy. This was not the case for South Africa, where the South African Law Reform Commission takes on this role, even though it consults with civil society. In the Singapore case, the issue of a day off policy for domestic workers was raised by several NGOs in a private meeting with a nominated Member of Parliament who then put the issue onto the Parliamentary agenda. This nominated MP that the NGOs approached had a long history of activism and concern for social justice, which helped the coalition. 


\section{CONCLUSIONS}

The three case studies presented in this article showed that gender and vulnerability were important contextual factors shaping the nature of migration policy in postcolonial countries. While we pay heed to drivers recognized in the larger literature based on western liberal democracies, including the role played by interest groups and the important influence of migration narratives in shaping policy change, we have chosen to scrutinize the empirical evidence from ground up to identify four main drivers of policy change.

First, the nature of the role players showed that international and local actors played a role in policy change even though local activism was given greater impetus by international actors. Coalitions were central to balancing the power relations between NGOs and government. However, the women for whom the policy was being developed were largely absent from the policy-making process. Second, the context of gender and vulnerability shaped the nature of the debates that occurred. In particular, debates took on a moral concern. There was also significant debate about whether women's work constituted work and whether the state was intervening in private arrangements. Third, whilst evidence-based policy-making has become a catch phrase in many contexts, in these case studies research had a tenuous and even tangential relationship to policy change. While it was valued it was also heavily contested and debated. Finally, the political context in each country shaped the nature of the policy change. We argue that in taking account of these factors advocates and policymakers can more effectively shift policy.

This article thus offers a tentative framework for understanding the policy process in contexts outside of western liberal democracies. As such it offers to those seeking to influence and make policy a set of factors likely to shape the process. Attention to these factors can result in more effective policy advocacy. In addition, an awareness of these factors can help to shape a debate on policy-making that is more evidence-based. For example, an awareness of how gender narratives shape policymaking for vulnerable women can ensure that, from the outset, policy influencers direct these debates in ways that ensure a more favourable policy outcome. Similarly, an understanding of the role of international organizations or coalitions can result in strategic alliances that better shape policy.

\section{ACKNOWLEDGEMENTS}

Migrating out of Poverty is funded by UK aid from the UK government; however the views expressed do not necessarily reflect the UK government's official policies.

\section{REFERENCES}

Ashraf, A.S.M.A.

2016 Public Policy Formulation: A Case Study of Domestic Workers in Bangladesh. Working Paper 37. Brighton. Migrating out of Poverty Research Programme Consortium, University of Sussex.

Asis, M.M.B., N. Piper and P. Raghuram

2009 "International migration and development in Asia: Exploring knowledge frameworks", International Migration, 48(3): 76-106.

Betts, A. (Ed.)

2011 Global Migration Governance. Oxford University Press, Oxford.

Betts, A. and P. Orchard (Eds.)

2014 Implementation and World Politics: How International Norms Change Practice. Oxford University Press, Oxford. 
Birkland, T.A.

2014 An Introduction to the Policy Process: Theories. Concepts and Models of Public Policy Making, Routledge, London.

Bonthuys, E.

2012 "The 2010 football world cup and the regulation of sex work in South Africa", Journal of Southern African Studies, 38(1): 11-29.

Chauvin, S. and B. Garcés-Mascareñas

2014 "Becoming less illegal: Deservingness frames and undocumented migrant incorporation", Sociology Compass, 8(4): 422-432.

Cohen, $\mathrm{S}$.

2002 Folk Devils and Moral Panics: The Creation of the Mods and Rockers. Psychology Press, Hove.

Collier, D.

1993 "The comparative method", in Ada.W. Finifter (Ed.), Political Science: The State of the Discipline II. American Political Science Association, Washington, DC: 105-119.

2011 "Understanding process tracing", PS. Political Science and Politics, 44(4): 823-830.

Collinson, S.

1993 Beyond Borders: West European Migration Policy Towards the 21st century. Royal Institute of International Affairs, London.

Consterdine, E.

2015 "Managed migration under labour: Organised public, party ideology and policy change", Journal of Ethnic and Migration Studies, 41(9): 1433-1452.

Critcher, C.

2008 "Moral panic analysis: Past, present and future", Sociology Compass, 2(4): 1127-1144.

Freeman, G.P.

2002 "Winners and losers: Politics and the costs and benefits of migration", in A.M. Messina (Ed.), Western European Immigration and Immigration Policy. Praeger, Westport Connecticut: 7796.

Gauvin, F.P.

2014 Understanding Policy Developments and Choices Through the' 3-i' Framework: Interests. National Collaborating Centre for Healthy Public Policy, Montreal, Ideas and Institutions.

George, A. and A. Bennett

2004 Case Studies and Theory Development in the Social Sciences. MIT Press, Cambridge, MA.

Green, S.

1999 "A plague on the Panopticon: Surveillance and power in the global information economy", Information, Communication \& Society, 2(1): 26-44.

Guiraudon, V.

2000 European Integration and Migration Policy: Vertical Policy-Making as Venue Shopping. Blackwell Publishers Ltd, Oxford.

Habib, A., and R. Taylor

1999 "South Africa: Anti-apartheid NGOs in transition", Voluntas: International Journal of Voluntary and Non-Profit Organizations, 10(1): 73-82.

Holms, S.M. and H. Castañeda

2016 "Representing the 'European refugee crisis' in Germany and beyond: Deservingness and difference, life and death", American Ethnologist, 43(1): 12-24.

Human Rights Watch

2005 Maid to order: ending abuses towards migrant domestic workers in Singapore. Research Report.

Human Sciences Research Council

2010 Tsireledzani: understanding the dimensions of human trafficking in Southern Africa. Research Report.

Jenkins-Smith, H.C., D. Nohrstedt, C.M. Weible, et al.

2014 "The advocacy coalition framework: Foundations, evolution, and ongoing research", Theories of the Policy Process, 3: 183-224.

Keck, M.E. and K. Sikkink

2014 Activists Beyond Borders: Advocacy Networks in International Politics. Cornell University Press, Ithaca. 
Koh, C.Y., C. Goh, K. Wee, et al.

2017a "Drivers of migration policy reform: The day off policy for migrant domestic workers in Singapore", Global Social Policy, 17(2): 188-205.

Koh, C.Y., K. Wee, C. Goh, et al.

2017 b "Cultural mediation through vernacularization: Framing rights claims through the day-off campaign for migrant domestic workers in Singapore”, International Migration, 55(3): 98-104.

Krut, R.

1997 Globalization and civil society: NGO influence in international decision-making, (Vol. 83).United Nations Research Institute for Social Development, Geneva.

Lipsky, M.

2010 Street-Level Bureaucracy: Dilemmas of the Individual in Public Services, 30th anniversary, expanded edn. The Russell Sage Foundation, New York.

Lombardo, E., P. Meier and M. Verloo (Eds.).

2009 The discursive politics of gender equality: Stretching, bending and policy-making. Routledge.

Migrant Forum in Asia

2006 Newsletter, 9 March 2006

Ministry of Manpower

2014 December 7. Survey shows about nine in 10 foreign workers satisfied working in Singapore. Retrieved from http://www.mom.gov.sg/newsroom/press-releases/2014/survey-shows-about-nine-in10-foreign-workers-satisfied-with-working-in-singapore (accessed in February 2018).

Mulchand, A.

2005 December 9. "Dispute goes on over maid abuse report", The Straits Times, Singapore.

Nagy Hesse-Biber, S. and P. Leavy

2011 The Practice of Qualitative Research. SAGE Publications, Thousand Oaks, CA.

Oishi, N. Women in Motion: Globalization, State Policies, and Labor Migration in Asia. Stanford University Press, Stanford.Palmary, I., and T. de Gruchy

2016 Changing Policy: Lessons from the Trafficking in Persons Act (2013) in South Africa. Working Paper 39. Brighton: Migrating out of Poverty Research Programme Consortium, University of Sussex.

Piper, N.

2006 "Gendering the politics of migration”, International Migration Review, 40(1): 133-164.

Risse, T., S.C. Ropp, K. Sikkink, et al.

1999 Power of Human Rights. Cambridge University Press, Cambridge: 264260

Sim, C.

2015 “SMRT bus drivers' strike”. In Singapore Infopedia. Retrieved from http://eresources.nlb.gov.sg/inf opedia/articles/SIP_2015-03-11_162308.html (accessed in February 2018).

Statham, P. and A. Geddes

2006 "Elites and the 'organised public': Who drives British immigration politics and in which direction?", West European Politics, 29(2): 248-269.

Stewart, J.

2012 "Fiction over facts: How competing narrative forms explain policy in a new immigration destination", Sociological Forum, 27(3): 591-616.

Swers, M.L.

2013 Women in the Club: Gender and Policy Making in the Senate. University of Chicago Press, Chicago.

Teo, Y. and N. Piper

2009 "Foreigners in our homes: Linking migration and family policies in Singapore", Population, Space and Place, 15: 147-159.

United States' Department of State

2010 Trafficking in Persons (TiP) Report. Retrieved from https://www.state.gov/documents/organization/ 142979.pdf (accessed February 2018).

Yeoh, B.S.A. and K. Annadhurai

2008 "Civil society action and the creation of 'transformative' spaces for migrant domestic workers in Singapore”, Women's Studies, 37(5): 548-569. 
Yeoh, B.S.A. and S. Huang

2009 "Foreign domestic workers and home-based care for elders in Singapore", Journal of Aging and Social Policy, 22(1): 69-88.

Yoo, G.

2008 "Immigrants and welfare: Policy constructions of deservingness", Journal of Immigrant and Refugee Studies, 4: 490-507. 